\title{
PENGARUH VARIASI KOMPOSISI PUPUK TERHADAP PERTUMBUHAN RUMPUT LAUT, Eucbeuma cottonii PADA KULTUR IN VITRO
}

\author{
Sri Amini") dan Andi Parenrengi**)
}

\begin{abstract}
ABSTRAR
Penelitian ini dilaksanakan di laboratorium Balai Penelitian Perikanan Pantai,Maros selama dua bulan dengan tujuan untuk melihat pengaruh variasi beberapa komposisi pupuk dalam media kultur terhadap perkembangan eksplan rumput laut, Eucbeuma cottonii secara kultur in vitro.

Penelitian dilakukan menggunakan botol-botol kultur volume $250 \mathrm{ml}$ yang diisi air laut $100 \mathrm{ml}$ salinitas $35 \%$ o . Botol kultur diinokulasi dengan 1 eksplan E.cottonii (panjang $1 \mathrm{~cm}$ ) dan disimpan dalam ruangan bersuhu konstan $25^{\circ} \mathrm{C}$, intensitas cahaya 1000 lux. Perlakuan pupuk meliputi: (A) Stok Conwy A + B + C, (B) Stok Conwy A + B, (C) Stok Conwy B + C, (D) Stok Conwy A, (E) Stok Conwy B, (F) Stok Conwy A + C, (G) $\mathrm{FeCl}_{3}+\mathrm{KNO}_{3}+\mathrm{Na}_{2} \mathrm{H}_{2} \mathrm{PO}_{4}$, (H) $\mathrm{NaH}_{2} \mathrm{PO}_{4} \mathrm{H}_{2} \mathrm{O}+\mathrm{NaNO}_{3}$ + mikronutrien.

Penelitian menggunakan rancangan acak lengkap (RAL) dengan 8 perlakuan dan 5 kali ulangan.

Hasil penelitian menunjukkan bahwa laju pertumbuhan tunas E.cottonii tertinggi diperoleh pada perlakuan A (Conwy media) yaitu 13,5\% perhari dengan panjang tunas 6,50 $\mathrm{mm}$ dan jumlah tunas 4 pada Minggu ke 8.
\end{abstract}

ABSTRACT: Effect of Various Kinds of Fertilizer to the Growth of Sea Weed, Eucbeuma cottonii During in vitro Culture, by: Sri Amini and Andi Perenrengi.

A 2 month study on the effect of various kinds of fertilizer to the growth of E.cottonii cultured in vitro was conducted at laboratory of the Research Institute for Fishery Coastal Aquaculture in Maros.

The objective of this experiment was to know the influence of various kinds of fertilizer which were applied in the media culture to the growth of E.cottonii young plant.

Experiments were done using glass bottle of $250 \mathrm{ml}$ filled with $100 \mathrm{ml}$ of sea water media of 35 ppt salinity. Each culture bottle was inoculated with 1 explant of E.cottonii $\left(3 \mathrm{~cm}\right.$ length) and stored in constant room temperature $\left(25^{\circ} \mathrm{C}\right)$ with light intensity of 1000 lux. Fertilizers applied were: (A) Conwy Stock A+B +C, (B) Conwy Stock A+B, (C) Conwy Stock B + C, (D) Conwy Stock A, (E) Conwy Stock B, (F) Conwy Stock $\mathrm{A}+\mathrm{C},(\mathrm{G}) \mathrm{FeCl}_{3}+\mathrm{KNO}_{3}+\mathrm{Na}_{2} \mathrm{H}_{2} \mathrm{PO}_{4},(\mathrm{H}) \mathrm{NaH}_{2} \mathrm{PO}_{4} \mathrm{H}_{2} \mathrm{O}+\mathrm{NaNO}_{3}$ + micronutrient.

The experiment used complate randomized design (RAL) with 8 treatments and 5 replications.

The result of the experiment shows that the highest growth rate of E.cottonii shoot was achieved by treatment A (Conwy media) which was $13,5 \%$ per day,reaching shootlength of $6.50 \mathrm{~mm}$ and number of shoot 4 at week 8 .

KEYWORDS: Seaweed, fertilizer

*) Peneliti pada Instalasi Penelitian Perikanan Laut Slipi, Jakarta

4*) Peneliti pada Balai Penelitian Perikanan Pantai, Maros 


\section{PENDAHULUAN}

Rumput laut, Eucheuma spp. tergolong dalam kelompok karaginofit yang dapat memproduksi karaginan berkisar 61,5-84,5\% (Atmadja, 1991). Karaginan merupakan salah satu bahan pembentuk suspensi, stabilizer, pengemulsi, gelling agent, dan thickening sehingga banyak diperlukan sebagai additive pada industri makanan, minuman, keramik, fotografer, farmasi, kosmetik, cat, dan lain-lain (Zatnika, 1994). Mengingat pemanfaatan bahan-bahan tersebut semakin meluas maka upaya budidaya merupakan langkah awal yang tepat dalam meningkatkan produksi rumput laut, sehingga diharapkan suplai produksi dapat teratur, baik dalam jumlah dan mutu.

Salah satu faktor penunjang keberhasilan budidaya rumput laut adalah benih yang digunakan. Benih yang digunakan harus berkualitas baik, bebas dari pengaruh pencemaran lingkungan, penyakit serta dapat tumbuh dengan cepat. Penggunaan benih dari stok alam seringkali memberikan hasil yang tidak maksimal. Untuk itu diperlukan alternatif lain untuk menumbuhkan benih rumput laut melalui metode kultur in vitro. Kultur invitro mengacu pada kultur jaringan (Gunawan, 1987). Aplikasi metode kultur in vitro telah dilakukan pada jenis rumput laut, Gracilaria verrucosa sejak tahun 1992 di Balai Penelitian Perikanan Budidaya Pantai, Maros. Penggunaan media Conwy pada penelitian G.verrucosa menunjukkan pertumbuhan tunas yang lebih baik dibandingkan beberapa komposisi pupuk dalam media yang dicobakan (Amini dan Parenrengi, 1994). Belum diketahui apakah metode tersebut memberikan pengaruh yang sama pada pertumbuhan rumput laut jenis Eucheuma spp.

Keberhasilan metode kultur in vitro sangat ditentukan oleh penggunaan media pupuk yang baik dengan komposisi yang tepat. Liao (1983) telah melakukan serangkaian penelitian untuk menumbuhkan mikro algae sebagai pakan larva udang. Dari penelitian tersebut ternyata beberapa formula media Conwy dan media yang tersusun dari beberapa senyawa pupuk terbukti bagus untuk menumbuhkan Skeletonema. Diperkirakan media serupa juga dapat digunakan untuk menumbuhkan Eucheuma spp. Untuk memastikan hal tersebut maka perlu dilakukan penelitian tentang pengaruh variasi pupuk dalam media kultur in vitro rumput laut E.cottonii mengacu pada pupuk kultur mikroalgae (Liao, 1983)

Penelitian ini bertujuan untuk melihat pengaruh variasi komposisi pupuk dalam media terhadap perkembangan eksplan rumput laut, E.cottonii yang dikultur secara in vitro di laboratorium.

\section{BAHAN DAN METODE}

Penelitian ini dilaksanakan di laboratrium Balai Penelitian Perikanan Pantai, Maros selama dua bulan pemeliharaan. Wadah yang digunakan adalah botol-botol kultur volume $250 \mathrm{ml}$ sebanyak 50 buah yang diisi air laut steril 
$100 \mathrm{ml}$ salinitas 35 ppt sebagai media pertumbuhan. Terhadap media tersebut kemudian ditambahkan pupuk sesuai perlakuan,dengan ketentuan: untuk stock Conwy A penambahan adalah sejumlah $1 \mathrm{ml} / 1$ media, stock B: $0,01 \mathrm{ml} / 1$ media, stock C: 0,1 ml/1 dan mikronutrien: $1 \mathrm{ml} / 1$ media (Appendix 1). Alat dan bahan yang digunakan disterilkan dengan menggunakan autoclave pada suhu $121^{\circ} \mathrm{C}$ selama 20 menit. Botol-botol kultur ditempatkan pada ruangan terkontrol pada suhu rata-rata $25^{\circ} \mathrm{C}$, dengan sumber cahaya berasal dari lampu tabung 40 watt, dengan intensitas cahaya 1000 lux.

Thalus rumput laut yang dicobakan adalah Eucbeuma cottonii yang berasal dari perairan Takalar, Sulawesi Selatan. Thalus rumput laut diseleksi kemudian dipotong menjadi eksplan sepanjang $3 \mathrm{~cm}$. Sebelum dimasukkan dalam botol kultur, eksplan dibersihkan kemudian dibilas dengan air laut steril. Setiap botol kultur diisi dengan 1 buah eksplan. Penggantian media (yang telah diberi pupuk) dilakukan 2 kali seminggu.

Sebagai perlakuan pada penelitian ini adalah variasi komposisi pupuk dalam media tumbuh kultur in vitro (Liao et al., 1983) yakni:

A. Conwy Stok $\mathrm{A}+\mathrm{B}+\mathrm{C}^{*}$

B. Conwy Stok $A+B^{*}$

C. Conwy Stok $B+C^{*}$

D. Conwy Stok $A^{*}$

E. Conwy Stok $B^{*}$

F. Conwy Stok $\mathrm{A}+\mathrm{C}^{*}$

G. $\mathrm{FeCl}_{3} 5 \mathrm{ppm}+\mathrm{KNO}_{3} 100 \mathrm{ppm}+\mathrm{Na}_{2} \mathrm{H}_{2} \mathrm{PO}_{4} 2 \mathrm{ppm}+11$ air laut

H. $\mathrm{NaH}_{2} \mathrm{PO} 4 \mathrm{H}_{2} \mathrm{O} 10 \mathrm{ppm}+\mathrm{NaNO}_{3} 150 \mathrm{ppm}+$ mikronutrien $1 \mathrm{ml}^{*}+$ 11 air laut.

*) see Appendix 1

Percobaan yang terdiri dari 8 perlakuan ini masing-masing menggunakan 5 ulangan. Rancangan yang digunakan adalah rancangan acak lengkap. Peubah yang diamati adalah pertumbuhan panjang tunas yang diukur setiap minggu dengan menggunakan mistar geser (caliper) dengan tingkat ketelitian $0,05 \mathrm{~mm}$ dan jumlah tunas dihitung pada akhir penelitian serta $\mathrm{pH}$ air yang diukur setiap penggantian media kultur.

Laju pertumbuhan panjang dihitung dengan menggunakan rumus Effendie (1979):

$$
\boldsymbol{K}=\frac{\boldsymbol{L}_{\boldsymbol{\gamma}}-\boldsymbol{L}_{0}}{\boldsymbol{L}_{\boldsymbol{0}}} \times 100 \%
$$

di mana: $\quad K=$ laju pertumbuhan panjang, $L t=$ panjang akhir dan $L o=$ panjang awal.

Pembahasan data hasil penelitian diuji dengan menggunakan LSD (Least Significant Difference by Student's T). 
Sri Amini dan Andi Parenrengi

\section{HASIL DAN BAHASAN}

Hasil pengukuran rata-rata panjang tunas setiap eksplan yang dicapai selama 2 bulan kultur in vitro di laboratorium menunjukkan adanya perbedaan antar perlakuan disajikan dalam Figure 1.

Lenght $(\mathrm{mm})$

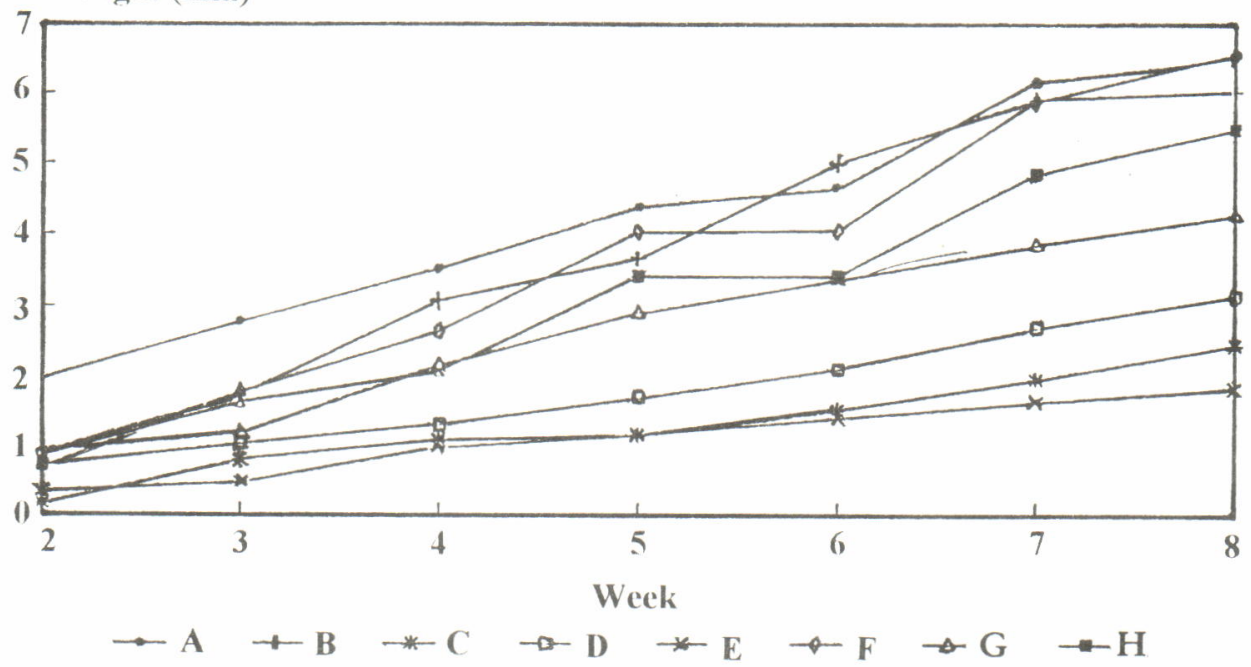

Figure 1. The weekly average length $(\mathrm{mm})$ of E.cottonii shoot of respective treatment

Tunas rumput laut, Eucheuma cottonii dapat mencapai panjang rata-rata 1,80-6,56 mm selama 2 bulan pemeliharaan di laboratorium (Figure 1). Panjang tunas tertinggi diperoleh pada perlakuan $\mathrm{F}$ kemudian $\mathrm{A}, \mathrm{B}, \mathrm{H}, \mathrm{G}, \mathrm{D}, \mathrm{C}$, dan terendah pada perlakuan E. Pada perlakuan $H$ walaupun penambahan konsentrasi fosfat cukup tinggi, tunas dapat tumbuh baik hal tersebut dimungkinkan pada perlakuan ini ada unsur mikroelement yang tercukupi yaitu dengan adanya penambahan mikronutrien.

Apabila dibandingkan dengan kultur in vitro rumput laut, Gracilaria verrucosa, maka pertumbuhan tunas yang dapat dicapai Eucheuma cottonii lebih panjang dibanding G.verrucosa yang hanya dapat mencapai panjang tunas rata-rata 1,09-2,92 $\mathrm{mm}$ selama 2 bulan kultur in vitro di laboratorium (Amini dan Parenrengi, 1994).

Rata-rata pertambahan panjang tunas setiap minggu berkisar 0,28-0,94 mm di mana pertambahan panjang tunas tertinggi adalah perlakuan $\mathrm{F}$ dan terendah pada pelakuan E (Table 1). Secara umum baik pada panjang tunas yang dapat dicapai maupun pertambahan panjang tunas setiap minggu menunjukkan bahwa perlakuan yang menggunakan larutan media Conwy stok A (makro nutrien) memperlihatkan keunggulan misalnya pada perlakuan $\mathrm{A}, \mathrm{B}, \mathrm{D}$, dan 
F. Seperti halnya dengan penelitian terdahulu yang dilakukan oleh Amini dan Perenrengi (1994) penggunaan Conwy stok A (makro nutrien) memperlihatkan pertumbuhan tunas yang lebih baik dibanding beberapa variasi komposisi pupuk yang dicobakan.

Table 1. Length gain of E.cottonii shoot

\begin{tabular}{cccccccc}
\hline Treatments & \multicolumn{7}{c}{ Week } \\
\cline { 2 - 8 } & $\boldsymbol{I}$ & $\boldsymbol{I I}$ & $\boldsymbol{I}$ & $\boldsymbol{V}$ & $\boldsymbol{V I}$ & $\boldsymbol{V I I}$ & $\boldsymbol{V I I}$ \\
\hline $\boldsymbol{A}$ & 1.98 & 0.79 & 0.75 & 0.88 & 0.25 & 1.52 & 0.34 \\
$B$ & 0.93 & 0.82 & 1.30 & 0.57 & 1.35 & 0.91 & 0.12 \\
$C$ & 0.17 & 0.65 & 0.29 & 0.06 & 0.38 & 0.42 & 0.48 \\
$D$ & 0.73 & 0.33 & 0.27 & 0.38 & 0.40 & 0.57 & 0.45 \\
$E$ & 0.37 & 0.12 & 0.51 & 0.32 & 0.21 & 0.24 & 0.17 \\
$F$ & 0.70 & 1.09 & 0.85 & 1.37 & 0.92 & 0.98 & 0.65 \\
$G$ & 0.93 & 0.28 & 0.96 & 0.72 & 0.72 & 0.48 & 0.57 \\
$H$ & 0.89 & 0.75 & 0.44 & 0.67 & 0.67 & 1.43 & 0.64 \\
\hline
\end{tabular}

Kalau dilihat kandungan dan komposisi Conwy stok $\mathbf{A}$, adalah satu-satunya stok yang mengandung Borium dan Mangan. Menurut Dwijoseputro (1988), Borium akan diserap oleh eksplan tanaman dalam bentuk $\mathrm{BO}_{3}{ }^{ \pm}$yang dalam air laut kandungannya sangat kecil, sedangkan Bhodjwani dan Resdan (1983) menyatakan bahwa apabila tanaman kekurangan Borium dan Mangan akan menyebabkan perlambatan, penghambatan perpanjangan dan pembelahan sel.

Rata-rata laju pertumbuhan panjang tunas tertinggi rumput laut, E.cottoni pada semua perlakuan yang masih hidup dan tumbuh terdapat pada perlakuan A dan F yaitu $13,5 \%$ (Table 2).

Table 2. Growth rates of E.cottonii (\%)

\begin{tabular}{crrrrrrr}
\hline Treatments & \multicolumn{7}{c}{ Week } \\
\cline { 2 - 8 } & $\boldsymbol{I I}$ & $\boldsymbol{I I}$ & $\boldsymbol{I V}$ & $\boldsymbol{V}$ & $\boldsymbol{V I}$ & $\boldsymbol{V I I}$ & $\boldsymbol{V I I I}$ \\
\hline $\boldsymbol{n y y y y y y y y}$ & 33.0 & 21.3 & 17.5 & 16.1 & 13.5 & 14.9 & 13.5 d \\
$B$ & 15.0 & 13.5 & 15.2 & 13.4 & 14.6 & 14.3 & 12.5 cd \\
$C$ & 2.8 & 6.3 & 5.5 & 4.3 & 4.4 & 4.7 & 5.0 ab \\
$D$ & 12.2 & 8.1 & 6.6 & 6.3 & 6.1 & 6.5 & 6.4 abc \\
$E$ & 6.2 & 3.8 & 4.9 & 4.3 & 4.1 & 3.9 & 3.7 a \\
$F$ & 11.6 & 13.7 & 13.2 & 14.8 & 11.8 & 14.2 & $13.5 \quad d$ \\
$G$ & 15.5 & 9.2 & 10.8 & 10.7 & 9.8 & 9.3 & $8.8^{\text {abcd }}$ \\
$H$ & 14.8 & 12.6 & 10.4 & 11.4 & 9.9 & 11.7 & 11.4 bcd \\
\hline
\end{tabular}


Walaupun secara uji statistik laju pertumbuhan ini tidak berbeda nyata dengan perlakuan $B, G$ dan $\mathrm{H}$ tetapi berbeda nyata dengan perlakuan lainnya. Hal tersebut terjadi karena mikro nutrien pada E.cottonii hanya sedikit diperlukan sehingga tanpa penambahan mikro nutrien (stok B) pertumbuhan tunas tetap baik, atau mungkin masih tersedia unsur mikro elemen antaranya $\mathrm{Co}, \mathrm{Zn}, \mathrm{Cu}$ dan lain-lainnya di dalam media air laut.

Jumlah tunas yang tumbuh per eksplan rumput laut, E.cottonii tidak menunjukkan perbedaan yang menyolok antar perlakuan, di mana setiap eksplan didapatkan rata-rata 2-4 tunas (Table 3). Jumlah ini jauh lebih rendah dari yang diperoleh pada kultur in vitro G.verrucosa yang mencapai rata-rata 11 tunas/eksplan (Parenrengi dan Amini, 1994).

Table 3. Average number of shoot of seaweed, E.cottonii explant

\begin{tabular}{cc}
\hline Treatment & Total exsplant \\
\hline$A$ & 4 \\
$B$ & 4 \\
$C$ & 3 \\
$D$ & 3 \\
$E$ & 3 \\
$F$ & 2 \\
$G$ & 3 \\
$H$ & 3 \\
\hline
\end{tabular}

\section{KESIMPULAN DAN SARAN}

Komposisi pupuk dalam media kultur jaringan yang memperlihatkan pertumbuhan tunas rumput laut, Eucheuma cottonii sp yang baik adalah perlakuan yang menggunakan media Conwy stok A (makro nutrien).

Dari semua perlakuan media rata-rata jumlah tunas yang tumbuh setiap eksplan adalah 2-4 tunas di mana jumlah tunas terbanyak adalah pada perlakuan A dan B.

\section{UCAPAN TERIMA KASIH}

Ucapan terima kasih diucapkan kepada Rifka Pasande, Reni Yulianingsih, dan Rosiana Sabang atas segala bantuannya dalam penelitian ini. 


\section{DAFTAR PUSTAKA}

Amini, S. dan A. Parenrengi. 1994. Perbanyakan benih Gracilaria verrucosa in vitro dengan perlakuan pupuk yang berbeda. J.Penelitian Budidaya Pantai, Maros. 10(2): 19-28.

Atmadja, W.S. 1991. Potensi dan spesifikasi jenis rumput laut di Indonesia. Dalam Suparno, A. Poernomo, E. Setiabudi, S. Saleh, T.D. Suryaningrum, dan S. Wibowo (Eds.) Prosiding Temu Karya Ilmiah Teknologi Pasca Panen Rumput Laut, Badan Penelitian dan Pengembangan Pertanian, Departemen Pertanian, Jakarta. p.1-14

Bhojwani, S.S. dan M.K. Resdan. 1983. Plant tissue culture; teory and practice. Elsevier, Amsterdam, Oxford, New York, Tokyo.

Bryan, G.W. 1971. The effect of heavy metals other than $\mathrm{Hg}$ on marine and estuarine organism. Proc.Roy.Soc.London.B 117: 389-410.

Dwidjoseputro. 1988. Pengantar fisiologi tumbuhan, PT. Gramedia, Jakarta.

Effendie, M.I. 1979. Biologi Perikanan Bagian I. Studi Natural Histologi. Fakultas Perikanan. Institut Pertanian Bogor, Bogor.105 hal.

Gunawan, L.W. 1987. Teknik kultur jaringan. Laboratorium Kultur Jaringan Tanaman, Pusat Antar Universitas (PAU) Bioteknologi IPB. Bogor. 253 p.

Liao, I.C., H.M. Su and J.H. Lin. 1983. Larval foods for penaeid prawns. In Mc Vey, J.P. and J. R. Moore (Eds.) CRC Handbook of Mariculture, Crustacean Aquaculture Volume I, CRC Press, Inc. Boca Raton, Florida. p.43-69.

Parenrengi, A. dan S. Amini. 1994. Kultur rumput laut, Gracilaria verrucosa in vitro pada berbagai panjang eksplan. J.Penelitian Budidaya Pantai, Maros. 10(2): 29-34.

Zatnika, A. 1994. Profil industri rumput laut Indonesia, Makalah disajikan dalam Simposium dan MUNAS APBIRI di Bali 8-9 Desember 1994. 12 hal. 
Sri Amini dan Andi Parenrengi

Appendix 1. Composition of Conwy Media and Micronutrient (Liao et al., 1983)

\section{STOCK A :}

\begin{tabular}{|c|c|c|}
\hline $\mathrm{FeCl}_{3} 6 \mathrm{H}_{2} \mathrm{O}$ & : & $1.30 \mathrm{~g}$ \\
\hline $\mathrm{MnCl}_{2} 4 \mathrm{H}_{2} \mathrm{O}$ & : & $0.36 g$ \\
\hline $\mathrm{H}_{3} \mathrm{BO}_{3}$ & : & $33.60 \mathrm{~g}$ \\
\hline$E D T A(N a$ Salt $)$ & : & $45.00 \mathrm{~g}$ \\
\hline $\mathrm{NaH}_{2} \mathrm{PO}_{4} 2 \mathrm{H}_{2} \mathrm{O}$ & : & $20.00 \mathrm{~g}$ \\
\hline $\mathrm{NaNO}_{3}$ & : & $100.00 \mathrm{~g}$ \\
\hline Distilled water & : & $1000.00 \mathrm{ml}$ \\
\hline
\end{tabular}

\section{STOCK B :}

$\mathrm{ZnCl}_{2}$

$\mathrm{CoCl}_{2} 6 \mathrm{H}_{2} \mathrm{O}$

: $2.10 \mathrm{~g}$

$\left(\mathrm{NH}_{4}\right)_{6} \mathrm{Mo}_{6} \mathrm{O}_{24} 4 \mathrm{H}_{2} \mathrm{O}$

$: 2.00 \mathrm{~g}$

$\mathrm{CuSO}_{4} \mathrm{SH}_{2} \mathrm{O}$

$: 0.90 \mathrm{~g}$

Distilled water

: $2.00 \mathrm{~g}$

Add $1 \mathrm{ml}$ stock $B$ per 1 liter of seawater

\section{STOCK C}

Vitamin $B_{12}$ (cyanocobalamin) : $10.00 \mathrm{mg}$

Vitamin $B_{1}$ (Thiamin) : $200.00 \mathrm{mg}$

Distilled water : $100.00 \mathrm{ml}$

Add $0.1 \mathrm{ml}$ stock $C$ per 1 liter of seawater

\section{MICRONUTRIENT MEDIA}

\begin{tabular}{|c|c|}
\hline $\mathrm{Na}_{2} \mathrm{EDTA}$ & $: \quad 7.3 \mathrm{~g}$ \\
\hline $\mathrm{FeCl}_{3}$ & $: \quad 6.0 \mathrm{~g}$ \\
\hline $\mathrm{Na}_{2} \mathrm{MoO}_{4} \mathrm{OH}_{2} \mathrm{O}$ & $: \quad 44.0 \mathrm{mg}$ \\
\hline $\mathrm{ZnSO}_{4} 7 \mathrm{H}_{2} \mathrm{O}$ & : $\quad 44.0 \mathrm{mg}$ \\
\hline $\mathrm{MnCl}_{2} 4 \mathrm{H}_{2} \mathrm{O}$ & $: \quad 360.0 \mathrm{mg}$ \\
\hline $\mathrm{CoCl}_{2} 6 \mathrm{H}_{2} \mathrm{O}$ & : $\quad 20.0 \mathrm{mg}$ \\
\hline $\mathrm{CuSO}_{4} 5 \mathrm{H}_{2} \mathrm{O}$ & : $\quad 2.0 \mathrm{mg}$ \\
\hline Distilled water to & $: 1.0 l$ \\
\hline
\end{tabular}

